Article

\title{
Rational Actors, Passive and Helpless Victims, Neither, Both: EU Borders and the Drive to Migrate in the Horn of Africa
}

\author{
Christopher Changwe Nshimbi ${ }^{1,2}$ \\ ${ }^{1}$ Centre for the Study of Governance Innovation (Govlnn), University of Pretoria, 0002 Pretoria, South Africa \\ ${ }^{2}$ Department of Political Sciences, University of Pretoria, 0002 Pretoria, South Africa; E-Mail: christopher.nshimbi@up.ac.za
}

Submitted: 7 October 2020 | Accepted: 28 December 2020 | Published: 25 March 2021

\begin{abstract}
This article argues that neither borders nor the ways in which migrants see them constitute significant deterrents to the migrants' resolve to migrate. The argument is based on an investigation of migrants en route to Europe from the Horn of Africa and the ways in which they see EU external borders and how that contributes to the decision to migrate. The article advances critiques of rational choice models of migrant decision-making that are based mainly on economic factors and contributes to theoretical explanations of why some people in the Horn of Africa migrate irregularly, despite measures enforced by state authorities to curb their movement. The article draws on a qualitative thematic analysis of personal face-to-face interviews conducted with migrants from four countries in the Horn of Africa who were in Ethiopia at the time of the research. In the interviews, there was sufficient evidence that migrants had realistic perceptions of European borders and that life in Europe might not be rosy. But this did not dampen the resolve to migrate. Solutions other than those that inhibit movement but understand, are sensitive to and include the perceptions of migrants are more likely to effectively address challenges associated with irregular migration.
\end{abstract}

\section{Keywords}

borders; European Union; Horn of Africa; migration; migrants' perceptions

\section{Issue}

This article is part of the issue "Decision-Making under Uncertainty: African Migrants in the Spotlight" edited by Didier Ruedin (University of the Witwatersrand, South Africa / University of Neuchâtel, Switzerland).

(C) 2021 by the author; licensee Cogitatio (Lisbon, Portugal). This article is licensed under a Creative Commons Attribution 4.0 International License (CC BY).

\section{Introduction}

Migration and the deaths of thousands of people attempting to cross the EU external border for refuge, better life and economic prospects were among the most prominent and dramatic events that dominated the first two decades of the 21st century. This culminated into the so-called 2015 European migration crisis, in which over a million irregular migrants crossed into the EU from the Middle East and Africa and allegedly threatened to undermine the EU culture and single market (Diez, 2019; Mezei, 2018; Rogelj, 2017). Although the majority of people migrating to Europe in 2015 probably came from Syria, mainstream media and some academic literature suggest that migrants originating from Africa through the Mediterranean Sea significantly contributed to the crisis (Crawley \& Skleparis, 2018; Flahaux \& de Haas, 2016;
Hammond, 2015; Inwood, 2017; Mackintosh, 2017; Mussi, 2018; Thorleifsson, 2017). Details of the migration events of 2015 are significant here because such events continue into the 2020s. As elaborated shortly, this article seeks to understand why this is the case from the perspective of migrants from the Horn of Africa. Migrants and asylum seekers from this region followed two major routes to reach Europe including, the Western Mediterranean from Morocco and Algeria into Spain and the Central Mediterranean from Tunisia and Libya through to Italy (Lampedusa). That irregular migration continues post-2015, with some of it originating in the Horn of Africa countries of Eritrea, Ethiopia, Somalia and Sudan.

The EU and member states responded to the crisis by reinforcing respective nation-state borders that had existed before they established the Schengen Area. 
The Common European Asylum System seemed to have been thrown into disarray. Particularly noteworthy was German Chancellor Angela Merkel's suspension of the Dublin Regulation in late 2015 in order to accommodate Syrian refugees (Holehouse, 2015; Scally, 2019). The suspension effectively meant that Germany defied EU rules or the Common European Asylum System, which required asylum seekers to seek refuge in the first safe EU country of arrival. This is also noteworthy because, as Belloni (2016) argues, the Dublin Regulation of the EU has not been able to prevent refugees from repeatedly trying to exploit possibilities of achieving legal status in second EU member states after they arrived in Europe, despite it being nearly impossible for them to gain asylum in second countries.

In the wake of the 2015 crisis, countries like Germany at the global level also backed the multilateral process that led to and culminated in the adoption of the Global Compact for Safe, Orderly and Regular Migration (GCM) in 2018. The assumption behind the GCM is that legal pathways constitute viable means for addressing irregular migration. The argument in this regard has, indeed, been made that irregular migration occurs because the EU or member states close off legal avenues for admitting regular migrants (Czaika \& Hobolth, 2016). The EU and member state's responses to the 2015 migration crisis as well as the drafting of the GCM, therefore, both seem to suggest that irregular migrants remain the target of restrictive migration legislation. Three quick points arise here in relation to what seems to be the major concern that irregular migrants from Africa in particular raise for governments, academics and anti-immigrant groups in the EU.

Firstly, some scholars, development and civil society organisations strongly indicate that more migration actually occurs within Africa than outwardly (Mercandalli et al., 2019; Nshimbi \& Fioramonti, 2016) for it to warrant concern within EU countries. Secondly, significant voluntary, orderly and safe (as opposed to irregular) migration of the type that the GCM and EU countries aspire to achieve also actually occurs within Africa than outward. But thirdly, discourses in policy, public and academic circles assume that African migrants opt to engage in irregular rather than regular migration to the EU (see, e.g., Crawley, Düvell, Jones, McMahon, \& Sigona, 2017; Ruedin \& Nesturi, 2018; Spencer \& Triandafyllidou, 2020). Within those debates, very few examine the role that the migrants' resolve to migrate plays in migration processes, seeing that irregular migration towards the EU continues to occur. While some studies examine why unauthorised migration occurs, less than a handful really examine actual individual choices to engage in irregular migration (Ruedin \& Nesturi, 2018). Further still, very little is known about the determination and motivations as well as how those individuals who opt to engage in irregular migration perceive processes of migration, especially physical barriers (like borders) enforced to curb their movement.
In this article I argue that the borders do not deter the migrants from their resolve to migrate. Accordingly, I investigate the ways in which African migrants who have already started off from their home countries on their irregular sojourn to the EU perceive the EU external border and the role of the migrants' attitudes towards the borders in the migration process. The article is set out within the context of the shared concern with irregular migration which I have highlighted. A proper understanding of individuals' views of apparent obstacles to irregular migration - such as borders -is essential to dispelling misleading assumptions about African migration that inform purported interventions to solve the problem. Efforts to protect and secure the EU's external border against unwelcome immigration are indeed said to have failed and the investments poured into them, wasted (Andersson, 2016; Castles, 2004).

Despite this, it is business as usual for both EU policy makers and the migrants. There is, however, research that adds agency to the understanding of African migration and distinguishes between African people's aspirations to migrate, the ability to migrate buoyed by their prosperity, and opportunities that present themselves for them to migrate (Flahaux \& de Haas, 2016). Similarly, other studies explore aspirations further and add to them, desire and drivers of migration (Carling \& Collins, 2020). These studies question common and widely held stereotypes of Africa as a continent attempting to escape poverty, war and pestilence (Flahaux \& de Haas, 2016).

I extend these works in an attempt to contribute to unravelling why some Africans undertake irregular migration despite EU states enforcing measures and running information campaigns to discourage them from migrating. In the article, I focus on migrants' resolutions that inform the ways in which they perceive and respond to borders as formidable obstacles to their movement. My central argument is that as far as the migrants are concerned, borders do not constitute significant obstacles to their intent to migrate. What really matters to them is what they actually do if or when they encounter the borders. This argument arises from the response to the question why Africans from the Horn of Africa seem so determined and attempt to migrate to Europe, despite knowing that barriers and challenges exist to their movement.

Belloni (2016, 2019) has investigated Eritrean refugees in Italy and why they try to acquire new refugee status in second EU member countries despite the measures in the Dublin Regulation designed to stop such practices as well as a range of risks inherent to irregular migration. Belloni (2019, p. 1) asks "why gamble resources, time and energy again for an unsure outcome," and uses a theory of gambling to argue that the refugees in Italy engage in a "migration lottery" of continuously attempting to proceed to northern European countries in search of asylum in the hope that it will be granted. This is because living conditions in Italy are poor. It is more so because as far as the refugees and 
their relatives are concerned, the refugees had not yet reached their final destination where they would fulfil family expectations and find safe havens and degrees of existential and socioeconomic stability. Belloni emphasizes luck, cost and reward of the bet or chances taken on migrating and the feeling of entrapment in the migration process already started as factors that compel the refugees to continue migrating until the process is completed. Whereas Belloni studies Eritrean refugees in Italy and their attempts to migrate further beyond to northern Europe, in this study I investigate secondary movement within Africa of not only Eritrean but also Ethiopian, Somalian and Sudanese migrants whose intended destination is Europe. I examine migrants who face the certainty of encountering the EU external border and the possibility of being sent back. Hence, why embark on such a journey in the first place? The empirical section of the article will show that the migrants were fully aware and extremely well-informed about the risks of migration, conditions in Europe, and border control measures. Their perceptions are largely accurate and reflect the reality of EU policies. The key insight that will emerge from the migrants is their determination to continue the journey to Europe despite what they know. The theoretical considerations and discussion of data and methods in the next two section provide the context within which I discuss these realities in the rest of the article.

\section{Migration and the Resolve to Migrate: Some Theoretical Considerations}

Examinations of migration decisions suggest the need for interpretations that go beyond commonly held explanations to better understand migration in the 21st century, because dominant explanations emphasise rational economic choices as drivers of migration. The neoclassical economics approach, for example, assumes that an abundant supply of labour exists in developing countries and this contrasts the abundant capital in developed countries. People from developing countries in search of better socioeconomic and living conditions, therefore, make rational decisions to migrate and take up work in developed countries. The new economics of migration complements the neoclassical economics approach in positing that an individual migrant's extended family helps decide too as well as shares in the costs and benefits of the individual member's migration.

The push-pull theory assumes rationality of the migrant too. Wage differentials between the migrant's country and the intended destination, levels of labour supply and demand as well as the migrant's desire for greater employment opportunities and aspirations for higher wages drive them into migrating. A range of factors within the migrant's country of origin too such as conflict, poverty and unemployment influence their decision to migrate.

These theories are distinct in terms of disciplinary background but complement each other (Massey et al.,
1993) in the analysis of human migration. Further attempts to explain migration extend the focus of these theories to shine the spotlight on migrants' aspirations, desire and the drivers of migration (Carling \& Collins, 2020). They foreground aspirations and desire and bring attention to migrants' subjectivities that interact with rational economic narratives in explaining drivers of migration. This article advances narratives of migration beyond economic rationality. Considering the ways in which migrants relate to migration possibilities, their capabilities and desire, the article adds on an examination of the role that resolutions and perceptions play in the migration process. Because the informants in this article had already initiated their migratory journeys, the article uniquely highlights migrants' convictions within motivations that they were better off leaving their homes than staying (Alpes, 2016; Carling \& Collins, 2020). The article extends this aspect of migrants' aspirations and desire in the drive to migrate and demonstrates the resolve among migrants already in the process of migrating to proceed to their desired destination, Europe. The resolve is strongly expressed in the responses some key informants gave during interviews. This article distinguishes itself from many studies of Africa-Europe migration by engaging with the subject from the viewpoint of the migrants.

\section{Obstacles to Migration and Power of Perceptions: Methods and Instruments}

\subsection{Data and Methods}

This article follows a qualitative research design. The primary data, which was collected through interviews, was subjected to qualitative content analysis. After it was prepared and organized for analysis, a lot of effort was made to carefully identify and then group the data into common and recurring themes found in the interview responses. The themes spoke to migrants' perceptions of borders, the impact of various kinds of information from a variety of sources on decisions to migrate and knowledge/understanding of life in Europe in the migration process. This condensed and coded information formed the basis of the discussion in the next section. For example, salient themes that suggested 'knowledge' or 'understanding' of the existence of borders, risks involved in or realities of migration or life in Europe formed the basis upon which some informants' responses were picked and presented as pieces of evidence in the article. Attitudes that suggested migrants' agency such as 'hard work' or 'try,' equally informed the analysis and pointed to their effort and resolve to migrate.

In all, 28 migrants provided this information through semi-structured interviews conducted as part of the Swiss Sub-Saharan Africa Migration Network pilot project. The respondents originated from four countries of the Horn of Africa including, Ethiopia, Eritrea, Somalia and Sudan. They all had already started off 
on their journeys to Europe and were, therefore, interviewed en route in Ethiopia. The purposive snowballing method was deployed to select seven respondents per country. The Eritrean migrants were interviewed in refugee camps in Tigray, Ethiopia; Sudanese migrants were interviewed in the city of Humera, in Tigray, bordering Sudan; and Somalian and Ethiopian migrants were interviewed in Addis Ababa, Ethiopia. The profile of informants was inclusive and diverse by design, capturing respondents by age group, gender and educational attainment. Fifteen of the respondents indicated that they were young, 10 said they were young adolescents and three said they were adults. The sample also included 13 females and 15 males. While graduates of junior and senior high school (12 and 9, respectively) dominated the sample, respondents who held diplomas (5) and certificates (2) or that had been trained in technical and vocational training institutions formed part of the sample too.

The interviews were conducted from February to July 2019 and facilitated by researchers in an Ethiopiabased think tank. No interpreters were necessary, as the data collectors were native speakers of the languages in which respondents conversed. The semi-structured interviews mainly focused on the migrants' narratives of their journeys. Follow-up questions sought to draw out information on how the migrants perceived borders and the migration processes. All the respondents had already made the initial move in their sojourn to Europe and were interviewed in Ethiopia. This distinguishes this study from others of its kind. Other studies interview people still at 'home,' who have not yet initiated but are pondering migrating, or are failed migrants or returnees (see, e.g., Alpes, 2016). The initial plan in this study was to employ the triangulation of methods of data collection namely, key informant interviews, focus group discussions and life story narratives. Unfortunately, due to the outbreak of the 2019 coronavirus disease (Covid-19) and declaration of the pandemic, it was not possible to undertake the latter two methods. This is because the target countries, like the rest of the world, enforced strict measures such as the closure of nation-state borders and restrictions on gatherings, which curbed the mobility of researchers and ability to hold focus group discussions. The researchers, therefore, had to limit themselves to key informant interviews only.

\section{The African Migrant, Perceptions and the EU Border}

\subsection{The Dangers of Irregular Migration and Perceptions of a Better Life in Europe}

Several studies argue that poverty, wars and conflict characterise Africa and the socioeconomic and political realities on the continent (Douma, 2006; Elbadawi \& Sambanis, 2000; Goodhand, 2003; Rustad, 2019). They go on to posit that this, along with factors such as environmental degradation, increases the propen- sity and forces Africans to migrate in search of better economic and livelihood opportunities (Dako-Gyeke, Kodom, Dankyi, \& Sulemana, 2020; Flahaux \& de Haas, 2016; Raleigh, 2011; Schwartz, 2018). The studies argue that Europe is the most preferred destination by these migrants (Flahaux \& de Haas, 2016; Lenoël \& Molinero-Gerbeau, 2018). According to the arguments presented in these studies, the capital abundant industrial countries of Europe promise better standards of living and offer socioeconomic prospects and opportunities that are absent in Africa. The promise of higher wages, greater opportunities for employment and better standards of living in EU countries theoretically present significant pull factors for migrants, according to these arguments. Accordingly, the migrants have a nirvana view of EU countries and aspire to live there. Specifically, economic opportunities including better jobs and incomes are among most commonly cited pull factors towards Europe.

Yet, it became clear during interviews with the migrants who were already in the process of migrating to Europe from Ethiopia, Eritrea, Somalia and Sudan that they had realistic expectations of what life might turn out to be for them after they got to Europe. The expectations were best underscored by a young male Somali migrant, who said:

We know that life in Europe is not a bed of roses. Let alone for migrants, even for Europeans, hard work is required to have a decent life. There is no easy money to be collected. We know for sure our family members coming from Europe may not tell us the ugly part of life in Europe. However, we are very sure that at least hard work in Europe pays well. With skill and education people can succeed a lot. That is why better quality of life is the attraction for many of us. Otherwise, racism, religious discrimination against Muslims and the moral decadence of European sexuality are things most Africans look at with contempt. (personal communication, 1 April 2020)

Much as they perceived life to be better in Europe, therefore, the migrants also expressed that there was no guarantee that it would be 'rosy.' Actually, the cited young Somalian assumed that life for Europeans themselves could be difficult without hard work. And he even ventured to suggest that his family members and relatives who had been in Europe might hide the ugly reality of difficult life for people back home who intended to migrate. But we see one aspect of the migrant's perception of life in Europe that contributes to strengthening the resolve to proceed with migrating there. This is the confident perception that hard work in Europe pays well and that skill and education can lead to success. Moreover, he points to a better quality of life that presumably comes with hard work, skill and education. The quality of life he mentions speaks to pull factors of migration (Dustmann \& Okatenko, 2014; Rasool, Botha, \& Bisschoff, 2012). But 
over and above this, his assumptions are informed by his perceived understanding that applying oneself through hard work, skill and education produces better outcomes in Europe.

It is also interesting to see the migrant lowered his expectations and revealed a sober judgement of what he expected of a life that even threatens racism and discrimination based on his religious orientation in Europe. However, even that does not seem to have changed the perception of his country of origin (just like the young Eritrean man cited in the next sub-section and his negative view based on the uncle's killing and father's imprisonment) and the destination.

Further, it was evident from the responses obtained from all respondents that they too, just like the young Somalian respondent above, knew the dangers and risks involved in irregular migration very well. In fact, the question was asked if the journey to EU countries was worth making given the obstacles that existed on the way. Most of the respondents framed the issue as an existential matter. A young adolescent Somali female's revelation in this regard was intriguing. She said:

People think that migrants do not know the risks involved. They consider us as innocent victims of fascinating stories created by human traffickers. This is not true at all. We are very realistic. We have not better life that would not allow us to take risk anyway. Life is all about opportunity cost. If the opportunity cost of going was more expensive than staying at home and languish in poverty and miserable life, why do you think people would decide to migrate than stay at home. It is a pure gamble. If you stay you are going to die of poverty anyway. Why not trying to achieve something meaningful or die trying. (personal communication, 21 April 2020)

The young lady raised interesting issues in her response. Castles (2004, pp. 209-210) underscores the role of migrant agency as a key issue in explanations of why the migration policies of European states and supranational organisations fail. In her response, the young adolescent Somali lady in this regard shrugs off victimhood and projects herself as a realistic risk taker. Her response corroborates Castles' argument that migrants are social beings who actively shape the migratory process in the quest for better outcomes for sending families and communities and themselves. The Somali lady also seems to be very calculating as she demonstrates that she made a cost-benefit analysis of migrating. She exhibits reasoning that is beyond the motive to migrate associated with the notion that leaving her country is better than staying (Alpes, 2016). And her view that the migration process is "a pure gamble" not only confirms her conscious risktaking attitude but the strong resolve to proceed, based on the way that she contrasts it with the motive to stay at home and die. She, like a young adolescent Eritrean male and a female adult Sudanese respondent, also knew that among the obstacles she was likely to face on her journey was the "death during travel" or "death on the sea" (personal communications, 8 April 2020, 4 May 2020, 20 May 2020). In fact, all respondents said they knew that the possibility existed of dying or getting captured along the way. They based this on what they had seen on television, their smart phones or heard from friends. Nonetheless, they would continue with the journey. The migrants seemed to be fully aware of both the dangers and risks involved in irregular migration and that they might not achieve a better life in Europe. Yet, this did not dampen their resolve to proceed with the migration.

\subsection{Intentions to Migrate and Perceptions of European Borders}

The resolve to migrate by the key informants is strongly expressed in the views of a young Eritrean male migrant:

Once you left your country to migrate to a foreign land, there is no alterative to perseverance and patience. I am not going back to Eritrea to the hand of a butcher that killed my uncle and imprisoned my father. If this time it failed, I will keep on trying until it is realized. I will not tire or retire until I make it. That is how thousands of Eritreans made it to Europe crossing treacherous terrains and the sea. (personal communication, 8 April 2020)

His response indicates a couple of issues in his resolve to continue with the migration to Europe. The issues actually extend beyond the motive (that drove him to embark on his journey in the first instance) that leaving is better. First, migrating to him was the only option. And that option demanded perseverance mixed with patience. Based on this, second is therefore the expression that he was prepared to never stop until he made it to Europe as desired. His resolve in this regard corroborates evidence in some studies that reveals that undocumented migrants employ complex strategies to weather forced repatriation through processes of return (Galvin, 2015; Kleist, 2017). Galvin's examination of undocumented Zimbabwean labour migrants in Botswana, for example, shows that they experience deportation as a constant threat and not a single event and this has become a normal part of their daily transnational lives. Third, the young Eritrean was inspired in his resolve to keep on trying by the success of thousands of fellow Eritreans gone before him. So too, the view that they made it to Europe because they did "not tire or retire" until they made it. Fourth, it is noteworthy that the young migrant's resolve was also driven by a negative perception based on negative experiences back home. That gave him the resolve not to return. Lastly, therefore, the migrant's response helps underscore the suggestion I make that a proper understanding of African migration in the 21st century, particularly towards destinations outside of Africa, is no exception insofar as concerns the need to go beyond 
dominant and widely held rational economics models of migration as well as advancements that integrate motivations and migrants' subjectivities regarding migration possibilities.

The young Eritrean's response and those of other migrants raise the question why they are so determined to migrate and do not see turning back as an option. An overlooked element that can be gleaned from the young Eritrean's response is political motivation. He had relatives killed and imprisoned in Eritrea. This made him an asylum seeker who might face death or prison back home. His experience shows that it is not just economic factors that might be significant in migrants' resolve to migrate. Political motivations have a role to play too. It is actually argued that many Eritreans living outside of the country are not ready to return because of human rights violations and they are opposed to the government there (Ambroso, Crisp, \& Albert, 2011). Eritrea is known for compulsory conscription of youths into unlimited military service. This is besides the restrictions which the government imposes on people's various freedoms like freedom of movement, freedom of expression and freedom of religion. The absence of meaningful political contestation that is evident in the hard-handed way in which opposition groups are treated; the absence of free, fair and regular elections; the arbitrary detentions; as well as persecutions of many people because of their ethnicity, social and political orientations or religion indicate the challenging political conditions, governance environments and systemic issues that compel some people in Eritrea and some of its neighbours to migrate (Nshimbi, 2018). Many studies and majority of policies posit that migration from such countries is largely driven by economic factors, which boil down to poverty and that the migration could be discouraged by highlighting the risks of migration. Information provided by migrants and further analysis, however, seem to suggest that focusing solely on the risks of migration ignores the risk of staying home or returning as respondents quoted in this article make clear.

The migrants also knew that nation-state borders existed and expected to encounter both the EU borders and the agencies and officials that enforce them. The migrants' knowledge of borders and enforcers resonates with the function of borders with respect to the crossborder movement of people and international migration. Borders in this respect are regulators of the movement of people, besides goods and services (Nshimbi, 2019; Wilson \& Donnan, 2012). They determine who should move, or not, between and across state territories. This is worth pointing out here because, generally, Africans should obtain a visa before traveling to Europe to not only permit their entry but also stipulate the purpose of travel. As alluded to so far, the migrants discussed in this article travel to EU member states for purposes of engaging in work. However, they lacked the visas required for them to enter Europe. Hence the label irregular migrants. Because they travel outside of the regulations, laws and international agreements that govern the movement of people between/across state territories (see, e.g., Sironi, Bauloz, \& Emmanuel, 2019; International Convention, 1990). Hence, also, the discussion of their experiences in this article.

All the informants were fully cognisant of the border, border policies and requirements. They also knew the consequences of encountering the border and border agencies if they did not possess the necessary visa or travel documents. But they had resolved to make the journey, nonetheless. An overwhelming majority of the migrants said they expected to meet European border officials in the course of the journey and only a few believed they would not. Among the former group of respondents, a young adolescent Sudanese female and a young adolescent Ethiopian male expressed the conviction that it was rare to escape the scrutiny of European border officials because the border officials were equipped with high technological systems for detecting the infiltration of migrants through their borders (personal communications, 18 May 2020). Although they did not specify the technological systems, a system to which they could have been referring might be the one that Spain deploys in its approach to irregular migration management where it focuses on detecting and apprehending irregular migrants early (Carling \& HernándezCarretero, 2011). The sistema integrado de vigilancia exterior (SIVE), as the system is called, centrally coordinates the interception of suspicious vessels based on information transmitted from mobile devices about the vessels to a central command. There is also EURODAC, a software system that captures asylum seekers' biometric information that is shared between EU members. The members can then use it to detect abuse such as applications for asylum in multiple member states.

Among the informants who believed they would not encounter border officials, a young adolescent female Sudanese, a young adolescent male Sudanese and a young adolescent female Somalian went on to say that EU borders were porous and easy to infiltrate (personal communications, 18 May 2020, 19 April 2020). They cited the influx of Syrian migrants into Southern Italy and that of West Africans into Spain via the Canary Islands to prove their claims.

But most of those who expected to encounter EU borders and officials said they expected the officials would be unwelcoming, cruel to them and uncompromising. A young adolescent Eritrean migrant from May Ayni refugee camp put it this way:

We know what the Italian border guards did to our people during the tragedy of Lampedusa. It could have been avoided. The migrants' cry for help was denied. Humanitarian support from a humanitarian rescue organization working on helping migrants was curtailed. They left them to die on the sea as a deterrent measure to other migrants. I do not expect any positive gesture from them at all. Yet, I will try my 
chance of sneaking around and getting to Europe unnoticed. (personal communication, 8 April 2020)

This migrant's response shows what he expected of the border officials in the anticipated encounter. It also shows his full knowledge and that he was well informed about the goings-on at the border, in border encounters with officials of EU member countries. He did not expect any positive outcome from an encounter with the border or in interactions with border officials. He knew, based on the experience to which he referred that even death at sea was possible. However, he resolved to proceed and take chances to sneak around the border. This shows that neither the prospect of being harshly treated nor the threat of suffering the most extreme and negative form of outcomes-death-in the migration process dampened the respondent's resolve to continue.

Despite the challenges and negative experiences that all the migrants anticipated to encounter with European borders and officials, all of them insisted they would nonetheless continue with the migration. We see here, again, determination to enter EU territory. This superseded the anticipation of borders marked by physical and technological infrastructure, stringent border enforcement and "unwelcoming," "cruel" and "uncompromising" border agencies and officials. It also superseded other measures designed to deter migration to Europe such as information campaigns that highlight the risks of migration.

\subsection{Deterring Irregular Migration to EU Countries and Information Campaigns}

Several research and policy studies recommend equipping (intending) irregular migrants with early legal and realistic information about risks and the dangers of migration (Angeli, Dimitriadi, \& Triandafyllidou, 2014; Omelaniuk, 2012; Triandafyllidou \& Maroukis, 2012). However, the evidence provided so far shows migrants' resolve to migrate notwithstanding such information. The informants clearly suggested that information campaigns designed to inform migrants en route to Europe about the risks or dangers of irregular migration are unlikely to significantly impact or deter them from migrating. Their responses to questions on where they obtained information about the migration process, the $\mathrm{EU}$ and life in EU countries provide further evidence of their resolve in the face of information campaigns and knowledge that risks and dangers of migration were an actual reality. A young adolescent Eritrean migrant had this to say about that reality:

I learned from colleagues who made it to Italy and Germany that there is great risk of losing one's life and being kept prisoner of the human traffickers operating from Libya. I think I must cross at least five countries before getting to Germany. I already crossed one from Eritrea to Ethiopia. Then via Sudan to Egypt and
Libya then finally to Italy and Germany. (personal communication, 8 April 2020)

This migrant had his route planned out and information campaigns to dissuade him, let alone his own knowledge of risks and dangers, could not cause a rethink of his planned passage through Sudan, Egypt, Libya and on to Italy and Germany. Actually, a young Sudanese migrant seemed to suggest that not even information on social media platforms could reliably inform decisions to rethink migration:

Social media is open to misinformation and disinformation. There is no mechanism of making sure that everything you get from social media is right. However, it remains to be one of the sources of information for migrants. Specially this is vital in alerting violent incidents happening on migration routes like the capsizing of migrants. (personal communication, 29 May 2020)

Social media for this migrant seemed to mainly have been a means through which to obtain important information about incidences of violence on migration routes. The response seems to suggest that the migrant relied more on family abroad as an information source and not campaigns on migration risk and dangers. This was confirmed by a response of another migrant who said:

As you know it very well almost every family have at least one member of the family in diaspora. We keep close contacts with family members in Europe to get valuable information about the route and life in Europe. As many who used the same information and made it to Europe later confirm to us, there is no reason to doubt the information they provide us. We believe it is true. (personal communication, 8 April 2020)

It is very clear from the cited responses that, if anything, the migrants possess state of the art information about the world in general and their intended destinations in particular. The majority of them were actually connected through smart phones and used them to obtain current virtual information. The information also included stories and images of people like them, attempting to make the journey to Europe but got intercepted, rescued or drowned in the Mediterranean Sea. And some of these events occurred on the same Mediterranean routes the migrants were planning to use. All the respondents also disclosed that they used their phones to communicate with families and friends back home, to keep them informed about their situation in the migration process. They also revealed that they used the phones to communicate with friends and members of families abroad, to keep connected with other migrants who were in the process of migrating and, some, to communicate with traffickers to get route information and information 
about destination country. The point to make out of this is that information campaigns aimed at dissuading migrants from engaging in irregular migration (Brekke \& Thorbjørnsrud, 2018; Musarò, 2019; Nieuwenhuys \& Pécoud, 2007) may not only carry similar information to what the migrants are already exposed and fail to discourage them from migrating. But migrants have access to other information sources too.

Therefore, it is also possible and easy for them to use their own sources to either substantiate or refute information presented in those campaigns. In fact, when asked how they learned about the countries to which they were migrating many of the migrants listed family members abroad, friends in those destination countries or returnees, social media, television and radio, other migrants, brokers and human traffickers. Hence, the knowledge available to migrants about their destination, indeed, influences the decision to migrate. But put together, it is clear that for the most part, the information that feeds the migrants is from people with whom they are connected or in their networks. The majority of them obtained their information from families, friends, other migrants and brokers and very few from social media, television and radio sources combined. The question, thus, is which of the two information sourcestheir own or that from information campaigns-do they appropriate and use as bases upon which to make migration decisions. From the evidence presented here, we can say human connections and not information campaigns constitute dominant and, therefore, more influential sources of information for migrants about destination country. The extent to which this information is accurate, especially when compared with that produced in information campaigns, is subject to debate. The extent to which it is received and believed in ways that make it contribute to migrants' resolve to migrate cannot be disputed.

\section{Concluding Remarks}

I conclude the article by moving away from the data to briefly muse over some of its implications for borders, information campaigns, civil society/academic scholarship, and, generally, the role that migrants' resolutions play in migration processes. My study of migrants from the Horn of African, who had already started off on their journeys and were in the migration process, challenges the idea that restrictive borders, policies and practices are a very effective way of stopping irregular migration. It equally questions the effectiveness of information campaigns that target (would-be) migrants to discourage them from migrating to Europe by touting restrictive borders and practices and highlighting risks and dangers of migration. Regarding the former, measures as well as physical and soft(ware) infrastructure and technologies are actually in place to 'protect' or 'secure' Europe's borders (Andersson, 2016). But their effectiveness is questionable. This is in view of the reality highlighted in the introduction of this article that irregular migration from the Horn of Africa continues post the so-called 2015 migration crisis. And concerning the latter, other studies corroborate the information provided by migrants in this article that underscores the failure of advanced and sophisticated technologies and border control measures to curb irregular migration from Africa (see, e.g., Andersson, 2016; Castles, 2004). Targeted information about dangers of migration and sombre stories of irregular immigrants' lives in Europe seem to have achieved little in terms of a rethink about embarking on unknown journeys among migrants too. Approaches to addressing irregular migration that deploy information campaigns are informed by rational choice assumptions that migrants desperately want to escape poverty, war and are attracted by prospects of better life in destination countries. If migrants are informed about the perils of irregular migration, the recommendation goes, they will not migrate. However, the migrants in this article said they were very aware of potential dangers they faced in migratory journeys but resolved to migrate nonetheless. The Horn of Africa, from which all the informants originated, has long and continues to be a major source of migrants destined to Europe. They continue to migrate despite the information to which they are exposed about the risks of migration and the touted protective and security measures to curb their movements.

In view of this, this article has attempted to extend research that centres on the role of aspirations and desires in migration to underscore the importance of migrants' resolve in shaping migration decisions. Attempts to understand irregular migration should transcend rational economic choice interpretations and rather consider how migrants themselves see the measures informed by such theoretical views and designed to regulate their movement. Migrants are already fully aware of the physical barriers to migration and the dangers and risks involved in irregular migration. This reality demands a better understanding of the migrants, apart from a fixation with enforcing borders. The article has shown that the migrants either have a dismissive attitude of EU borders and downplay their effectiveness or are ready to encounter them and the border officials. Their resolve makes them ready to keep on trying to cross into EU territory to the point of death.

This finding is consistent with Belloni's $(2016,2019)$ examination of secondary refugee movements in Europe triggered by unpalatable conditions in the refugees' first country of arrival. Whereas the refugees would be expected to stay in that country, or to even return to their country of origin, it is shown that the EU's migration policies driven by the intention of the Dublin Regulation to stop the refugees from seeking asylum in second EU countries fail to prevent the refugees from doing so. The refugees mediate the effect of such policies with the way in which they perceive risk; with what they expect of migration; and how they view the EU policy restrictions as barriers which they must overcome 
and not hindrances to their migration (Belloni, 2016). On its part, this article has shown that even when still in Africa, migrants expect to face physical obstacles and even the threat of losing life itself, during the migration process. They are already aware of the tightened policies designed to restrict entry into Europe and are also well informed about restrictive border measures, infrastructure and software such as SIVE and EURODAC. Yet, they set their eyes on attaining to the life to which they aspire in Europe. This implies that fixation with the physical barriers at the margins of the EU as the point at which to curb irregular migration is counterproductive as the associated activities are ineffective.

The determination to migrate also, finally, indicates a couple of issues the literature on migration tends to either misrepresent or fails to emphasise. It dispels assumptions that migrants in Africa embark on journeys for which they lack information. Majority of the informants in this article had smart phones, which they used for communication and to access information and news on world events and their desired destinations. This corroborates Carling and Hernández-Carretero (2011), who contrary to Koser and Pinkerton's (2002) assertion that informal social networks of migrants spread stale information about conditions and policies in destination countries, argue that the migrants consider themselves better informed to the extent that they dismiss as biased propaganda, any seemingly biased information in campaigns that warn of the risks of migration. The resolve, therefore, also indicates migrant agency, an important consideration for any who would want to properly understand irregular migration from Africa. The point must be emphasised that irregular migrants are neither mere rational economic actors nor passive and helpless victims in migration processes. They are perceptive in an aspirational manner and this drives them to take risk to the point of a daring perseverance in migration processes. Push factors such as harsh political and governance conditions only strengthen the migrants' agentive resolve to move on and not return and face possible death or imprisonment. Initiatives other than those that attempt to inhibit movement but understand, are sensitive to, and include the perceptions of migrants are more likely to effectively grapple with the challenges associated with irregular migration.

\section{Acknowledgments}

Research for this article was made possible with generous funding from the Swiss Sub-Saharan Africa Migration Network (S-SAM), University of Neuchâtel, under the project "What You See Is What You Get: Perceptions of European Borders and the Drive to Migrate." The author acknowledges the data collection support of fieldworkers in the Horn of Africa and is also grateful to two anonymous reviewers for their critical engagement with the text and constructive feedback.

\section{Conflict of Interests}

The author declares no conflict of interests.

\section{References}

Alpes, M. J. (2016). Brokering high-risk migration and illegality in West Africa. London: Routledge.

Ambroso, G., Crisp, J., \& Albert, N. (2011). No turning back: A review of UNHCR's response to the protracted refugee situation in Eastern Sudan. UNHCR. Retrieved from http://www.unhcr.org/cgi-bin/ texis/vtx/home/opendocPDFViewer.html?docid= 4eb3e5ea9\&query $=2011$

Andersson, R. (2016). Europe's failed 'fight' against irregular migration: Ethnographic notes on a counterproductive industry. Journal of Ethnic and Migration Studies, 42(7), 1055-1075.

Angeli, D., Dimitriadi, A., \& Triandafyllidou, A. (2014). Assessing the cost-effectiveness of irregular migration control policies in Greece (MIDAS Policy Paper). Athens: ELIAMEP.

Belloni, M. (2016). Refugees as gamblers: Eritreans seeking to migrate through Italy. Journal of Immigrant \& Refugee Studies, 14(1), 104-119.

Belloni, M. (2019). The big gamble: The migration of Eritreans to Europe. Oakland, CA: University of California Press.

Brekke, J. P., \& Thorbjørnsrud, K. (2018). Communicating borders-Governments deterring asylum seekers through social media campaigns. Migration Studies, 8(1), 43-65.

Carling, J., \& Collins, F. L. (2020). Introduction: Aspiration, desire and drivers of migration. In J. Carling \& F. L. Collins (Eds.), Aspiration, desire and drivers of migration (1st ed., pp. 1-18). Abingdon and New York, NY: Routledge.

Carling, J., \& Hernández-Carretero, M. (2011). Protecting Europe and protecting migrants? Strategies for managing unauthorised migration from Africa. The British Journal of Politics and International Relations, 13(1), 42-58.

Castles, S. (2004). Why migration policies fail. Ethnic and Racial Studies, 27(2), 205-227.

Crawley, H., Düvell, F., Jones, K., McMahon, S., \& Sigona, N. (2017). Unravelling Europe's 'migration crisis': Journeys over land and sea. Bristol: Policy Press.

Crawley, H., \& Skleparis, D. (2018). Refugees, migrants, neither, both: Categorical fetishism and the politics of bounding in Europe's 'migration crisis.' Journal of Ethnicand Migration Studies, 44(1), 48-64.

Czaika, M., \& Hobolth, M. (2016). Do restrictive asylum and visa policies increase irregular migration into Europe? European Union Politics, 17(3), 345-365.

Dako-Gyeke, M., Kodom, R. B., Dankyi, E. K., \& Sulemana, A. (2020). Drivers of independent migration among adolescents from selected West African countries. Children and Youth Services Review, 117. https://doi. 
org/10.1016/j.childyouth.2020.105293

Diez, G. (2019, April 5). The migration crisis and the future of Europe. The American Prospect. Retrieved from https://prospect.org/world/migration-crisisfuture-europe

Douma, P. (2006). Poverty, relative deprivation and political exclusion as drivers of violent conflict in Sub Saharan Africa. ISYP Journal on Science and World Affairs, 2(2), 59-69.

Dustmann, C., \& Okatenko, A. (2014). Out-migration, wealth constraints, and the quality of local amenities. Journal of Development Economics, 110, 52-63.

Elbadawi, E., \& Sambanis, N. (2000). Why are there so many civil wars in Africa? Understanding and preventing violent conflict. Journal of African Economies, 9(3), 244-269.

Flahaux, M. L., \& de Haas, H. (2016). African migration: Trends, patterns, drivers. Comparative Migration Studies, 4(1). https://doi.org/10.1186/s40878015-0015-6

Galvin, T. M. (2015). 'We deport them but they keep coming back': The normalcy of deportation in the daily life of 'undocumented' Zimbabwean migrant workers in Botswana. Journal of Ethnic and Migration Studies, 41(4), 617-634.

Goodhand, J. (2003). Enduring disorder and persistent poverty: A review of the linkages between war and chronic poverty. World Development, 31(3), 629-646.

Hammond, T. G. (2015). The Mediterranean migration crisis. Foreign Policy Journal. Retrieved from https:// www.foreignpolicyjournal.com/wp-content/ uploads/2015/05/150519-MediterraneanMigration-Crisis-Timothy-G-Hammond.pdf

Holehouse, M. (2015, August 24). Germany drops EU rules to allow in Syrian refugees. Telegraph. Retrieved from https://www.telegraph.co.uk/news/ worldnews/europe/germany/11821822/Germanydrops-EU-rules-to-allow-in-Syrian-refugees.html

International Convention on the Protection of the Rights of All Migrant Workers and Members of Their Families, 1990, resolution 45/158. Retrieved from https://www.ohchr.org/en/professionalinterest/ pages/cmw.aspx

Inwood, J. (Producer). (2017). Migrants in the Mediterranean: Anatomy of a sea rescue in 360 video [Short]. UK: BBC. Retrieved from https://www.bbc. co.uk/news/resources/idt-sh/migrants_in_the_ mediterranean

Kleist, N. (2017). Disrupted migration projects: The moral economy of involuntary return to Ghana from Libya. Africa, 87(2), 322-342.

Koser, K., \& Pinkerton, C. (2002). The social networks of asylum seekers and the dissemination of information about countries of asylum. London: Home Office, Research Development and Statistics Directorate.

Lenoël, A., \& Molinero-Gerbeau, Y. (2018). West African migration to Mediterranean countries and agricul- tural work. In CIHEAM (Eds.), MediTERRA 2018 (English): Migration and inclusive rural development in the Mediterranean (pp. 57-77). Paris: Presses de Sciences Po.

Mackintosh, E. (2017, August 29). Europe's migrant crisis isn't going away, but it is changing. CNN International Edition. https://edition.cnn.com/2017/ 08/17/europe/mediterranean-migrant-crisis-2017/ index.html

Massey, D., Arango, J. G., Hugo, G., Kouaouci, A., Pellegrino, A., \& Taylor, J. E. (1993). Theories of international migration: A review and appraisal. Population \& Development Review, 19(3), 431-466.

Mercandalli, S., Losch, B., Belebema, M. N., Bélières, J. F., Bourgeois, R., Dinbabo, M. F., . . Nshimbi, C. C. (2019). Rural migration in Sub-Saharan Africa: Patterns, drivers and relation to structural transformation. Rome: FAO and CIRAD.

Mezei, B. M. (2018). The migration crisis \& the culture of Europe. The European Conservative, 2018(15), 12-19. Retrieved from https://european conservative.com/wp-content/uploads/eurocon_ 15_2018_summer-fall_dig.pdf

Musarò, P. (2019). Aware migrants: The role of information campaigns in the management of migration. European Journal of Communication, 34(6), 629-640.

Mussi, F. (2018). Countering migrant smuggling in the Mediterranean Sea under the mandate of the UN Security Council: What protection for the fundamentalrights of migrants? The International Journal of Human Rights, 22(4), 488-502.

Nieuwenhuys, C., \& Pécoud, A. (2007). Human trafficking, information campaigns, and strategies of migration control. American Behavioral Scientist, 50(12), 1674-1695.

Nshimbi, C. C. (2018, February 20). Repatriating migrants misses the point. Systemic issues need to be tackled. The Conversation. Retrieved from https://theconversation.com/repatriating-migrantsmisses-the-point-systemic-issues-need-to-betackled-88809

Nshimbi, C. C. (2019). Life in the fringes: Economic and sociocultural practices in the Zambia-MalawiMozambique borderlands in comparative perspective. Journal of Borderlands Studies, 34(1), 47-70.

Nshimbi, C. C., \& Fioramonti, L. (2016). Regional migration governance in the African continent. Current state of affairs and the way forward. Bonn: Development and Peace Foundation.

Omelaniuk, I. (Ed.). (2012). Global perspectives on migration and development: GFMD Puerto Vallarta and Beyond. Dordrecht: Springer.

Raleigh, C. (2011). The search for safety: The effects of conflict, poverty and ecological influences on migration in the developing world. Global Environmental Change, 21(Suppl. 1), 82-93.

Rasool, F., Botha, C. J., \& Bisschoff, C. A. (2012). Push 
and pull factors in relation to skills shortages in South Africa. Journal of Social Sciences, 30(1), 11-20.

Rogelj, B. (2017). The changing spatiality of the 'European refugee/migrant crisis.' Migracijske i Etničke Teme/Migration and Ethnic Themes, 33(2), 191-219.

Ruedin, D., \& Nesturi, M. (2018). Choosing unauthorized migration: Evidence from return migrants. International Migration, 56(4), 235-249.

Rustad, S. A. (2019). Conflict trends in Africa, 1989-2018: An update. Oslo: PRIO.

Scally, D. (2019, September 5). For good or ill, September 2015 was the making of Angela Merkel. The Irish Times. Retrieved from https://www.irishtimes.com/ news/world/europe/for-good-or-ill-september2015-was-the-making-of-angela-merkel-1.4008843

Schwartz, S. A. (2018). War, climate change, and migration. Explore, 14(3), 172-176.
Sironi, A., Bauloz, C., \& Emmanuel, M. (Eds.). (2019). International migration law no. 34: Glossary on migration. Geneva: International Organization for Migration.

Spencer, S., \& Triandafyllidou, A. (Eds.). (2020). Migrants with irregular status in Europe. Cham: Springer International Publishing.

Thorleifsson, C. (2017). Disposable strangers: Far-right securitisation of forced migration in Hungary. Social Anthropology, 25(3), 318-334.

Triandafyllidou, A., \& Maroukis, T. (2012). Migrant smuggling irregular migration from Asia and Africa to Europe. Basingstoke: Palgrave Macmillan.

Wilson, T. M., \& Donnan, H. (2012). Borders and border studies. In T. M. Wilson \& H. Donnan (Eds.), A companion to border studies (pp. 1-25). Hoboken, NJ: Blackwell Publishing.

\section{About the Author}

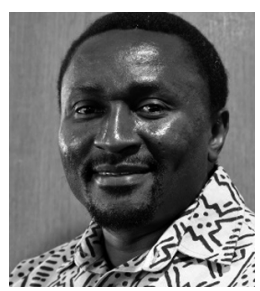

Christopher Changwe Nshimbi (PhD) is the Director of the Centre for the Study of Governance Innovation (Govlnn) and Senior Lecturer in the Department of Political Sciences at the University of Pretoria. He researches migration, borders, regional integration, the informal economy and water governance. Dr Nshimbi sits in on regional and international technical working groups on trade, labour and migration and water governance. Besides supervising postgraduate research, he also teaches on regional integration, African politics and regions, state formation and governance in Africa. Find him on Twitter @csn_chris 